\title{
PSYCHOLOGICAL AND PEDAGOGICAL ACCOMPANIMENT OF A FOSTER FAMILY FOR FORMATION OF ORPHANED CHILDREN'S FAMILY VALUES
}

\section{Dobrovolska N. A.}

\section{INTRODUCTION}

The dynamics of growth and the scale of development of orphanhood have become characteristic features of the social reality of the modern Ukrainian society, actualizing the need for studying various forms of social assistance for the living arrangements of the orphaned children. Of particular importance today are the studies of alternative forms of living arrangements for the children deprived of parental care. The family is an indispensable institution of socialization of a child, which allows her to master the basics of role-based behaviour in the assimilation of the social life standards. The priority of family upbringing is enshrined in international and Ukrainian legislation, however, more than 50,000 children deprived of parental protection are still being raised in specialized institutions for orphaned children ${ }^{1}$.

The reforming of the Ukrainian society to a large extent exacerbated the social problems of the population, which primarily affected its most vulnerable categories. New social groups and new social relations appeared, the socio-economic system changed, the value-semantic guidelines in the institutions of socialization changed. The alienation of parents from children, the growth of family deformation processes, the destruction of traditional moral and ethical principles, social ties, the deterioration of children's health, insufficient funding of the social sphere - all this led to a decrease in the level of protection of each person, and especially children. Such phenomena testify a deep destabilization of the society, the negative processes which are acquiring a national scale and pose a real threat to the national security. The decrease of the upbringing

\footnotetext{
${ }^{1}$ Комплексна допомога бездоглядним та безпритульним дітям: метод. посіб. / авт.: Безпалько О.В.; Гурковська Л.П.; Журавель Т.В. та ін. / за ред. Звєрєвої І.Д., Петрочко Ж.В. - К.: Видавничий дім «КАЛИТА», 2010. - 376 с.
} 
potential of a modern family, on the one hand, and the objective need to raise an orphaned child in the family conditions on the other hand, have become the prerequisites for creating an alternative institution for raising children who are, for various reasons, deprived of their family environment - the institution of a foster family. The process of its formation chronologically coincided with the period of transformation of the social protection system of the population, and therefore had a spontaneous character. The social need, which took shape, could not find a conceptual basis for effective realisation.

The phenomena of dysfunctions that arise during the functioning of the modern institution of the foster family are still being solved without sufficient scientific justification. On the theoretical level the structural features of the institution of the foster family and its functional potential have not been researched. Fundamental importance have the sociopedagogical characteristics of the positive and negative aspects of the institution of the foster family, the analysis of the basic prerequisites for its formation, achievements and miscalculations in its regulation, and on this basis, the development of adequate practical measures to increase the efficiency of its functioning.

To date, there has been a situation in which, on the one hand, we note the insufficient formation of the motivational complex for adopting a child into a family by adoptive parents, the lack of formation of family values in orphans, which requires the development of the content and methods of psychological and pedagogical accompaniment of this category of children.

\section{The concept of psychological and pedagogical accompaniment of the personality in the scientific literature}

The concept of "accompaniment" in the psychological and pedagogical scientific literature is often regarded as a synonym for support, assistance, compassion, cooperation, as a method and creation of specific conditions of mostly leading activity. Such understanding is found in the works of O.S. Gazman, S. Kurinna, A. Mashkarynets-Butko, G.M. Bevz, O.V Bespalko, L.P. Gurkovska, T.V. Zhuravel, V.V. Kuzmin, O.Ya. Shyshko, I.V. Manokhina.

Scientists consider psychological accompaniment as help to a child in making an independent choice of the life path. They emphasize that 
psychological accompaniment is a holistic process including the operational field of development, formation and correction of a personality, including several stages into this process: diagnostics, gathering information about problem solving methods, consultation at the decision-making stage, help at the implementation stage. So, O.S. Gazman introduced the concept of psychological and pedagogical accompaniment for children in solving individual problems associated with difficulties in physical and mental development and against their background, life selfdetermination, interpersonal communication and learning ${ }^{2}$.

The purpose of psychological and pedagogical accompaniment for children with special educational needs, according to A.G. Obukhivska, in the city's educational institutions is the study of personal potential and namely: the correlation of the level of mental development of the child and the age norm, the development of the cognitive sphere, the formation of motivation for learning; features of the emotional-volitional sphere; individual and characterological features, their creative and intellectual development through the involvement of all participants in the educational process (parents, teachers, children) in the implementation of the planned actions regarding the peculiarities of the development, communication, training; socialization and adaptation; vocational guidance for children with special needs ${ }^{3}$.

The concept of "pedagogical accompaniment" is presented in the works of E.G. Malynochka ${ }^{4}$, A.V. Kholod, V.L. Kholod and it envisages a process of interested observation, counseling, personal participation, encouraging the maximum independence of a child in a problem situation, the ability of a pedagogue to be near, follow a pupil, accompanying him or her on the individual educational route ${ }^{5}$.

Pedagogical accompaniment as a collaboration providing problemfree interaction, is considered in the concept of O.Ye. Kucherova. The researcher considers the dependence in the pedagogue-student interaction,

\footnotetext{
${ }^{2}$ Газман О.С. Педагогическая поддержка детей в образовании как ин-новационная проблема [Текст]/ О.С. Газман // Новые ценности образования: десять концепций и эссе. 1995. № 3. С. 58-63.

${ }^{3}$ Психологічний супровід інклюзивної освіти : [метод. рек] / автор. кол. за заг. ред. А.Г. Обухівська. Київ : УНМЦ практичної психології і соціальної роботи, 2017. - 92 с.

${ }^{4}$ Малиночка Э.Г. О педагогическом сопровождении формирования и развития личности [Текст]/ Э.Г. Малиночка. // Известия Академии педагогических и социальных наук. - 2008. - Ч. II. - C. 162-168.

${ }^{5}$ Холод В.Л., Холод А.В. Социально-педагогическая защита детей и молодежи в процессе психологопедагогического сопровождения в условиях единого воспитательного пространства сельского района [Текст] / В.Л. Холод, А.В. Холод // Известия Академии педагогических и социальных наук. - 2008. Ч. II. - C. 196-202.
} 
which consists in the fact that the pupil cannot solve the task independently and needs objective help, and the pedagogue cannot solve the student's task, since he will deprive him of his independence, and, therefore, the necessary development ${ }^{6}$.

We consider the psychological and pedagogical accompaniment as a condition for the successful development and psychological health of the orphaned children, which ensures the best assimilation of basic family values and practical knowledge, skills and abilities. We consider it a holistic process, the main components of which are the creation of conditions for the development of family life competencies and personal achievements, as well as monitoring the formation of relevant knowledge and skills.

Paying attention to the experience of various specialists in the formation of family values of orphaned children and children left without parental care in the conditions of a foster family we note the following: no document has a record of the mandatory preparation of orphaned children and children without parental care, to family life; the availability of programs to prepare nurselings for family life, the formation of views on the family depends on the activity and personal position of the administration and specialists in the field of accompaniment of this category of children.

In the process of the study, we have processed the programs which are actually operating at educational institutions and social organizations, aimed not only at preparing for family life, but also the formation of family values, beliefs about the family ${ }^{7}$. Their analysis showed:

1. The preparation for an independent family life and for the transition to a foster family is practically not carried out simultaneously in any institution for orphaned children and children left without parental care, and only one of the areas of preparation is being observed.

2. The transition of orphaned children and children left without parental care from one form of arrangement to another is carried out without taking into account the age and sex of the child, his or her

\footnotetext{
${ }^{6}$ Кучерова О.Е. Становление Человека и основные каноны педагогической поддержки личности [Текст] / О.Е. Кучерова // Известия Академии педагогических и социальных наук. - 2008. - Ч. II. C. 174-178.

7 Курінна С. Проблема соціального супроводу дітей дошкільного віку в дитячому будинку / С. Курінна // Актуальні проблеми психолого-педагогічного та соціального супроводу дитини на ранніх етапах со-ціалізації. Гуманізація навчально-виховного процесу: Спецвипуск 4, Част. 1. - Слов'янськ. 2010. - C. 198-203.
} 
ethnicity, etc., which does not fully reflect the process of forming family values in this category.

3. The educational programs do not sufficiently represent the system of work on the formation of family feelings between brothers and sisters living in the family conditions.

4. Not fully considered is the set of measures aimed at interaction in the system "parent-child", "child-child", etc.

In addition, the analysis of the experience of psychological and pedagogical accompaniment of orphaned children and children left without parental care in the conditions of a foster family allowed us to highlight a number of conditions necessary for the formation of family values in orphans and children left without parental care.

These may include:

1. Creating a favorable psychological climate for the family, where in orphaned children and children left without parental care the perception of the world, people and himself, moral feelings and emotions, moral knowledge about good and evil are formed; where the family team has a complex structure enshrined in customs, traditions, moral and legal norms, within which children, parents, grandparents are united by a whole system of relations - between elder and younger children, between children and parents. These very relationships determine the value of the family for orphans and children left without parental care, leave a unique imprint on the child - after all, it is in the family that a child acquires knowledge, abilities and skills in various fields and, above all, in the field of communication, human relations, and also gets the experience of living together.

2. Creating a success situation for orphaned children and children left without parental care makes it possible to achieve significant results both for a single individual (in this case, an orphan child), and for the team as a whole, namely for the family. The success situation is especially important in dealing with orphaned children and children left without parental care, whose behavior is complicated by a variety of external and internal causes, as it allows them to eliminate aggression, overcome isolation and passivity. Orphaned children in a situation of success receive a feeling of satisfaction from the fact that the results of their activities exceeded their expectations. In turn, the adoptive father leads his nurseling progressively upward, climbing with him the ladder of 
knowledge, psychological self-determination, gaining faith in himself and people around him. An important role in this process have pedagogical situations specially prepared by parents in the conditions of a foster family in which the child gets an opportunity to reveal unexpectedly his own abilities for himself. Father may not prepare such situations on purpose, but his educational potential will be manifested in the fact that he will not miss this moment, he will evaluate it correctly and will be able to materialize it. The main condition for creating a success situation is communication as a process of interconnection and interaction of subjects (groups, individuals), in which takes place an exchange of activities, information, experience, capabilities, abilities and skills, as well as the results of activities; one of the necessary and general conditions for the formation and development of the society and individual. The real intermediaries of all forms of communication in the "foster family orphaned children" system are not only the results of spiritual activity ideas, values, ideals, feelings and moods, but also material things - tools and means of human labour, objects that embody social values and human experience. The above mentioned allows to say that in the process of communication value-social experience is transferred and assimilated, there is a change in the essence of interacting entities (orphaned children and children left without the care of parents and foster parents), value relationships are formed and socialization of a personality takes place.

3. Increasing motivation for adopting children to a foster family. In the formation of family values in orphaned children and children left without parental care, the stage of preparing foster parents plays a significant role. Great importance is attached to developing among foster parents a real awareness of the motives and expectations from adopting a child, an adequate assessment of their own resources that will be required for successful socialization and upbringing, as well as identification of possible risks and threats. Based on the analysis of programs and research, the following factors of the efficiency or inefficiency of foster families can be distinguished:

- the ability of the family to become involved in the new social roles that arise in the process of joining the family system by new members;

- personal characteristics of foster parents, in particular, the flexibility of role-playing behavior; 
- the possibility or absence of a satisfactory information exchange on the upbringing of orphaned children and children left without parental care;

- the length of institutional stay (the length of stay in an orphanage);

- non-inclusion of a foster family into the system of psychological and pedagogical assistance and accompaniment, etc.

Thus, the study of the experience of the state educational and social institutions with foster families allowed us to identify the most effective conditions, as well as the leading areas of activity of various specialists and ways of forming family values in orphaned children and children left without parental care.

A necessary condition is the creation of a multifunctional accompaniment service, built on the principle of individual and joint activity of all subjects of the educational process - pedagogues, educators, parents based on subject-subject relations. However, it should be noted that in educational and social institutions attention is paid only to subjects of the educational process, namely, to the pupils and teachers, while foster parents remain involved in the process of accompaniment of orphaned children and children left without parental care. The above mentioned actualizes the activities of educational and social institutions, which should act as the center of interaction of the system "foster family - specialists of social institutions - pedagogues of educational institutions".

\section{Comprehensive program of psychological} and pedagogical accompaniment of a foster family for the formation of orphaned children's family values

The theoretical study of the problem allowed us to develop a comprehensive program of psychological and pedagogical accompaniment for the foster family, that is, for foster parents and orphans. This comprehensive program was implemented in Mykolayiv regional orphanage (the city of Mykolayiv). The comprehensive program of psychological and pedagogical accompaniment of the foster family includes the following blocks: target, content-related, organizational and monitoring. The purpose of the comprehensive program of psychological and pedagogical accompaniment is the formation of family values in orphans and children left without parental care in the conditions of a foster family. Due to the fact that the formation process is carried out in a foster family with the participation of various subjects (professionals who carry 
out the accompaniment, parents, children themselves), the target block also includes target guidelines for foster parents in the conditions of the orphanage, which is the main basis for the experimental study. These guidelines consisted in the pedagogical accompaniment of parents on the basis of the purposeful formation of their common pedagogical culture and competence which ensures the creation of the emotional well-being of the orphaned child in the family and subsequent adaptation, the formation of a value attitude to the world, to the family, to other people, to himself and self-realization in society. The content-organizational block reflects the specifics of the content of psychological and pedagogical accompaniment of foster parents in accordance with the main functions of the pedagogue, pedagogical tools for its implementation at different stages of the formation of the foster family for the formation of family values in orphaned children and children left without parental care. The main components of the comprehensive program of psychological and pedagogical accompaniment of the foster family, orphaned children and children left without parental care for the formation of family values are presented in Figure 1.

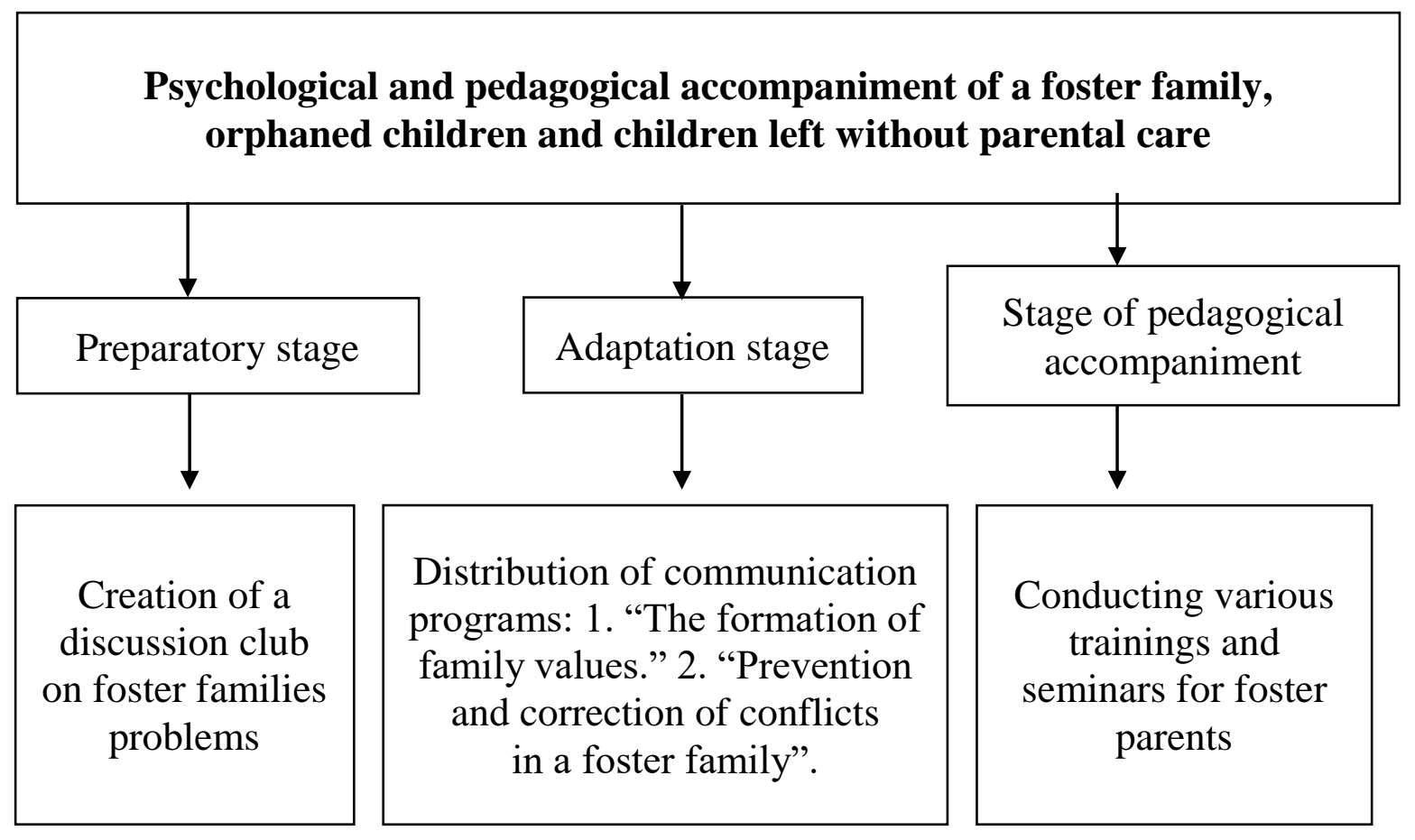

Fig. 1. Comprehensive program of psychological and pedagogical accompaniment for foster families, orphaned children and children left without parental care 
The implementation of the comprehensive program includes several stages: preparatory, adaptation and supportive. Let us consider these steps.

1 . The preparatory stage of psychological and pedagogical accompaniment of a foster family included the development and testing of the theoretical module of the training program with foster parents, as well as with experienced foster parents in the framework of the discussion club on foster families problems, which was invariant (unchanged), focused on any contingent of parents. The result of work at this stage is the increase of the level of foster parents' socio-psychological and pedagogical competence; mastering the ways of positive communication and interaction with the child; receiving psychological and emotional support.

2 . At the adaptation stage, a practical module was developed and put into practice, including the programs "Formation of family values", "Prevention and correction of conflicts in a foster family", which were of a variable nature and were adapted to the needs and problems of foster families. The result of this stage is the optimization of parent-child relationships, increasing the level of pedagogical competence of foster parents, increasing the level of formation of family values in orphaned children and their readiness for self-realization in society.

3 . The stage of pedagogical support to psychological and pedagogical accompaniment of foster families is aimed at implementation of a set of activities (trainings, seminars, courses, etc.) that complement the content of the above mentioned programs, taking into account the needs of the foster family and orphaned child in obtaining additional knowledge about the family, family values, own "Self". The result of this stage is the exchange of experience between foster parents, the interaction of all entities involved in working with foster families, orphaned children and children left without parental care, further development of family values in orphaned children and children left without parental care. All these stages do not have clear boundaries and are complementary.

The monitoring block provided the check of the effectiveness of the implementation of the comprehensive program of psychological and pedagogical accompaniment for foster parents and presented a system of step-by-step pedagogical diagnostics of the motivation for adopting an orphaned child into the family and the level of formation of family values in orphaned children and children left without parental care in a foster family. The logic of the stages, the implementation of the comprehensive 
program of psychological and pedagogical accompaniment of the foster family for orphaned cgildren and children left without care, depended on the results of the ascertaining stage of the research work and the peculiarities of the problem field of foster families.

Let us characterize in more detail the content-related and organizational block of the comprehensive program of psychological and pedagogical accompaniment of foster parents. At the first stage preparatory - a discussion club was created to discuss the problems of adoptive parents. The purpose of work of foster parents' discussion club is the psychological and pedagogical education of foster parents, help in preserving and strengthening of the psychological health of orphaned children and parents, promotion in creation of a wider network of contacts of foster parents with children, the increase of knowledge of foster parents on organizing family activities, forming family values in orphaned children and children left without parental care. The main objectives of the activities of the foster parents discussion club are: expanding and deepening the knowledge of parents in the field of preschool and school psychology and pedagogy; determination of the circle of common problems that arise in families raising orphaned children and children left without parental care; teaching foster parents of ways of positive communication and interaction with orphaned children; self-esteem of parental positions, overcoming stereotypes of parental behavior; providing emotional support to foster families, club members. In the course of the club's activities, trainings were held for parents for the topics: "Learning to understand each other", "Feelings of parents and children. Rules for the manifestation of feelings", "Family and family interaction." After conducting training sessions, the participants exchanged impressions about their work in the group, analysed the results of joint activities, that is, reflection was carried out. The coaches of the training sessions note the desire of the foster parents to attend classes aimed at studying the motives of the "good" and "bad" behaviour of the children, identifying their resource opportunities for raising orphaned children and the formation of family values in them. It is important to note that the implementation of the program envisaged holding classes aimed at all club members, as well as classes which are determined by the needs and problems of foster families. Their content was targeted, taking into account the particularities of socialization of orphaned children and children left without parental care, 
the level of professional competence of foster parents in the formation of family values. The variability and consideration of the problem field of an individual family made it possible to make the process of accompaniment of foster parents personality-oriented and targeted.

\section{Analysis of the results of implementation of a comprehensive program on living arrangements for orphaned children and children left without parental care in Mykolayiv regional orphanage}

The experimental data were collected through questionnaires, testing, observation, and then studied and worked out, which allowed us to give a qualitative analysis of the results received. The research and experimental work included three stages: ascertaining, forming, control and analytical. The purpose of the ascertaining stage is to identify the problematic field of formation of family values in orphaned children and children left without parental care in conditions of a foster family. Let us note that the specificity of the purpose and content of the experimental work required from us to conduct simultaneous diagnosis of parents - candidates for foster parents and orphaned children which determined the solution of the following tasks at the first stage of the experimental work: 1) to determine the motivational complex for the adoption of orphaned children and children left without parental care by foster parents; 2) to identify the initial level of formation of family values in orphaned children and children left without parental care. At first, we carried out a diagnosis of foster families, which allowed us to obtain general information about the composition and level of preparedness of future parents, and to identify the motivation for choosing a foster child. To obtain general information, we used a method - analysis of documents. To do this, we analysed statistical data on parents of foster families and candidates for foster parents.

Direct work was also done to advise foster parents. So, a foster father raising 4 orphans and children left without parental care, came to the orphanage with a problem associated with the aggravation of relations with the child (11 years old), who had been raised in the family for 1 year 4 months. The conflict situation is due, according to the foster father, the presence of certain hostility on the part of two children previously adopted into the family (3 years). In order to solve the situation, not only the specialists of the orphanage were involved in the work with the family, but also the participants of the parents' discussion club. In another case, it was 
necessary to combine the efforts of the family, accompaniment specialists and pedagogues of the orphanage. After accepting Stepan V. (10 years old) for foster care, the child lost the desire to study, despite the fact that he had this desire before the death of his biological parents, the foster parents failed to establish the reason for the child's unwillingness. In the process of work of psychologists and pedagogues it was found out that children who studied together in a comprehensive school teased him, calling him "a bastard." Having done appropriate work with classmates, teachers, parents and psychological and pedagogical rehabilitation with Stepan V., the indicators of motivation to study increased. Joint work with parents helped to establish the relationship of the teenager with foster parents, it demonstrated to Stepan V. the sincere desire of the parents to help him in solving his problems. The examples given show the need for a variant component conditioned by the individual factors of the child's stay in the family, his or her psychological characteristics. The result of the lessons was the establishment of emotional contact of the child with the father, the awareness of the peculiarities of communication with family members, understanding the need for creating conditions for trustful communication with children.

At the adaptation stage there were implemented the programs "My Family Values" and "Prevention and Correction of Child-Parent Conflicts". The specific character of the program "My Family Values" is in implementation of a systematic approach to the formation of family values. The program included the following content blocks:

1. "I am a family man" (work with a child): preservation of a positive attitude to his past and his family and formation of a sensible position "I am a family man";

2. "I am a father" (the development of a motivational complex for the adoption of a child, the level of pedagogical culture and the formation of parental competence in the formation of family values in orphaned children).

The purpose of the program: formation of family values in orphaned children. The main tasks of the program "My Family Values" are:

1. Creating a psychological and pedagogical space that fosters a positive attitude towards the family.

2. Creation of a family orientation, favorable conditions that contribute to the actualization of family values. 
3. Teaching the basics of social interaction as a condition of full-scale self-realization in society and family.

Within the framework of the program implementation, the following forms of psychological and pedagogical accompaniment were used: thematic seminars, workshops and trainings, educational games, discussions, as well as consultations held outside the organized collective classes at the parents' request. A psychologist, a social pedagogue and a family psychologist participated in the program. In the course of the implementation of the block of work with the child ("I am a family man" block) various methods, techniques and forms of conducting lessons were used: conversations - in order to establish problems of the child, to explain to him or her family traditions, rules of life in the family, etc.; a training lesson "My roots", which is aimed at helping to realize the influence of the past on life, rejecting stereotypes of negative behaviour; a course of behavioural therapy aimed at correcting the behaviour of orphaned children, teaching to control emotions; thematic lights - "You and Your Parents", "Mom' is the First Word", games "Home", "Family - I" aimed at actualizing the role of mother and father in shaping the family values of orphaned children, the role of the family in a person's life; competition program "Brother, sister and I are a close-knit family", focused on restoring lost family ties; the course "Preparing children for family life", which considers the culture of a family behaviour, the alphabet of family communication, family nutrition, means of communication with relatives, family health, life safety in the family, useful economy, family holidays, housekeeping, etc. A positive moment of realization of this block is the filling in the "Book of Life". This book is a story of the child himself, a chronicle of what really happened and why. Each child chooses his own form of book. For the child to be able to trace his or her growth visibly in the conditions of foster care, he or she is invited to start in the Book of Life a page of achievements individual map called "Path to the top named "I". The map is a pyramid consisting of numerous conventional bricks on which the child writes down his or her new achievements. The children, characterizing the positive experience of keeping the "Book of Life", noted: "..." The book of life" helps me to know myself...", "keeping the book helped me to revise my view of the world", "I began to understand the value of the family I found", "Now you can see my life as a dark stage that has remained in the past, and a light one, which is now and ahead...". 
The work with foster parents ("I am a father" block) included: group classes with training elements "What is my family?", "Learn your parental Self", "Family upbringing styles", "Conflict resolution", aimed at defining the concept and family functions, attitude to the upbringing process, drilling of cooperation skills and equal relations with the child; meetings with representatives of guardianship authorities, - police, a narcologist, a family psychologist, in order to resolve the issues of restoring a child's biological family, organizing work with children of the "Risk group", restoring parent-child relationships. The actions arranged were aimed at the development of familial, friendly relations between foster parents and orphaned children, as well as with other family members. In the course of the study, we observed the following: a manifestation of the desire to live together in a family, help each other, listen and respect the elders, take care of the younger ones, as well as a positive attitude towards adoptive parents, grandparents, a desire to live in a secured family, with family holidays and traditions. As part of the program activities, various types of exercises were used to form the components of family values. So, in order to form the understanding of gender family roles and respect for them, we used the exercise "Compliments", which develops communication skills, goodwill, and positive attitudes towards each other. Our observations allow us to note the respectful attitude of boys to girls, the manifestation of courtship, masculinity and femininity, empathy.

The program "Prevention and correction of parent-child conflicts" was also implemented in the conditions of the Orphanage. The main goal of the program is to provide psychological and pedagogical accompaniment for foster families, create conditions for the successful adaptation of orphaned children and children left without parental care in a foster family, and the prevention of parent-child conflicts and the formation of family values in orphaned children. As part of the program, specialists, together with representatives of departments of the system for the prevention of parentchild conflicts in orphaned children, provided assistance to a foster family to solve these problems. During the period of the experimental study, at the adaptation and supportive stages of our research work, a set of activities was carried out - trainings, seminars, courses aimed at studying the features of upbringing of orphaned children, the formation of socially significant and family values, the exchange of experience between adoptive parents and the interaction of all entities involved in work with foster families. 
Our role in the implementation of the content-related and organizational block of the program of psychological and pedagogical accompaniment was to mentor and individually accompany the foster family, in order to prevent abandonment of the orphaned children as a result of a conflict situation, misunderstanding of the age characteristics of children and lack of knowledge on their upbringing. According to our observations, the children felt satisfaction from their new position, fulfilled the instructions of their parents desirably, felt joy and anxiety at the same time, anxiety due to the fear of losing their parents. At the same time, we observed that other children previously accepted into the family felt jealous of their parents and rejection of new children in the family. For our part, we have determined an individual plan for foster family accompaniment, including training sessions, individual and group consultations aimed at relieving tension and uniting the family. According to the results of the work, there was a positive dynamics in family relations. The newcomers began to communicate more closely with other children, family members and others. The elder children in the family with a great desire began to help with housekeeping, to carry out joint jobbing, to take more responsible attitude to homework. Foster parents are satisfied with their role and the situation in the house; they are pleased that the children have taken root well in the family.

The control and evaluation of our work was carried out by almost everyone who took part in this process. The main thing for us was the assessment of the children themselves, who gained experience in family education. Let us quote the children: "the family is a reliable pier which saves from any adversity, helps in a difficult situation", "in the family you are loved just because you exist, not demanding anything in return", "for me the family is something beautiful and unattainable, what I never had and what I want to create. I want to see how people cling to each other, I want to be a link in this strong chain, I want to trust and rely." It is necessary to note the changes in the views of adoptive parents on the process of raising orphaned children and children left without parental care, and the formation of family values. Here are some reviews and opinions of parents: "The club is very necessary in the upbringing of both foster and natural children. Firstly, this is an acquaintance of foster families. Previously, we knew practically nothing about each other. And now we have not only learnt, begun to communicate and started 
celebrating some holidays together, making calls, consulting and sharing experience. The club taught us to understand our children better, to look at life through their eyes, to deal with the most difficult situations. During the classes you can get an individual consultation. And just become more selfconfident, recharge yourself with lots of positive energy"; "The school of foster parents allows you to feel that you are not alone with your problems. You feel relaxed and self-confident. The pedagogues are excellent specialists in their field; I thank them very much for everything. When problems pile up and you don't know what to do, it seems that the world is collapsing and there is no one to help. Now you can already afford it. And there were so many problems before. It's a pity that the school didn't arise earlier. Now I know what to do in one case or another. And, most importantly, who to contact. A few points that came in handy for me and will be needed in the future: the language of acceptance and rejection (intonation of voice, posture) plays a very large role, which I did not know and did not even imagine that it was so important. Thank you so much for everything and everyone. School is very important and necessary"; "I used to think that I knew all or almost everything about upbringing children. But after our lessons, I realized that I was deeply mistaken. You helped to look at orphaned children upbringing and family values formation in a different way. Now, before making any decision, I will think it over once more, I will remember our lessons"; "I learned not only to listen, but also to hear children. Many tips help to understand children's behavior and accept them for who they are. The school is especially needed when you are just starting out. The specialists of the school teach how to react and evaluate children correctly. I'm not a psychologist, I'm just a mom, without special education, at the classes I learned how to find a way out of conflicts, I learned to see the child from the inside. I was once again convinced that raising a child is difficult, and our children with wounded souls are special. And now I know that, having asked for help, I will receive it without fear of being ridiculed. I thank you very much as mother!"

In general, as we see from the above examples, the implementation of the comprehensive program has yielded positive results. For experimental verification of the effectiveness of the comprehensive program of psychological and pedagogical accompaniment of the foster family, orphaned children and children left without parental care, we organized a control phase of diagnosis. According to the "Me and My Family" 
questionnaire, we note an increase in the number of orphaned children and children left without parental care, with high and middle level and a decrease - with a low level. The dynamics of the formation of family values according to the questionnaire "Me and My family" are shown in Figure 2.

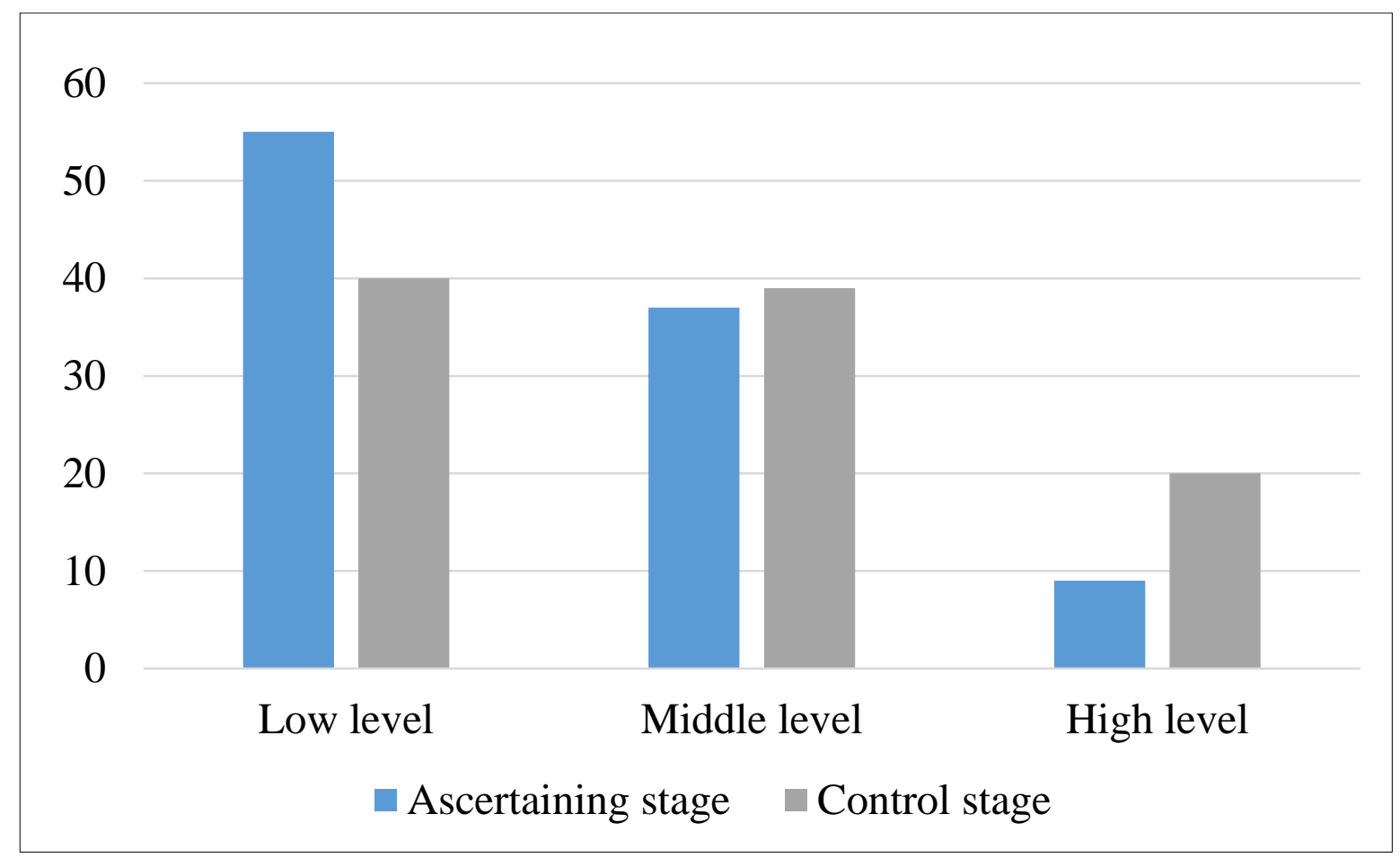

Fig. 2. Dynamics of family values formation in orphaned children

The share of the children with a high level of formation of family values increased from 9 to $20 \%$. In this group of children there is respect for elders, care for younger ones, willingness to help all the members of the family (need-motivational, emotional, activity-practical criteria). But at the same time, neuropsychiatric disorders are noted in the orphaned children and the children left without parental care which impede the formation of family values to the full extent (emotional aspect).

The middle level is a characteristic of $39 \%$ of orphaned children. In this group mutual understanding and mutual assistance in the family are manifested, family values are accepted, but there are motives that attract children more with rest and leisure rather than with understanding the importance of family recreation, family leisure and family traditions (needmotivational criterion). 
The number of respondents with a low level decreased from $55 \%$ to $40 \%$. They noted the presence of discomfort (emotional aspect), the occasional participation in family affairs, and the presence of difficulties in establishing contacts between family members (activity-practical criterion). However, it should be noted that in the conclusion of our experiment no home escapes were committed, which testifies to the child's desire to live in family.

Thus, the obtained results show that most orphaned children and children left without parental care positively changed their views on the family, on the organization of family life; there can be marked expressed family values, such as respect for elders, participation in family affairs, friendly relations with all family members, etc., which, in our opinion, testifies to the effectiveness of the measures taken as part of a comprehensive program of psychological and pedagogical accompaniment for orphaned children and children left without parental care. So, the conducted study allowed us to increase the level of formation of family values in orphaned children and children left without parental care, in the conditions of a foster family, which allows us to talk about its effectiveness.

\section{CONCLUSIONS}

The analysis of the domestic practice of psychological and pedagogical accompaniment of foster families proved the objective contradictions between the recognition of the need for a purposeful process of forming family values in orphaned children in the conditions of a foster family and the unsystematic nature, fragmentarity of such activities in the real practice of family upbringing and psychological and pedagogical accompaniment of family living arrangements for orphaned children.

The practice of upbringing confirms the need to pay closer attention to preparing foster parents for organizing the process of family upbringing and the process of forming family values in orphaned children, and organizing psychological and pedagogical accompaniment for such process.

The content and methods of psychological and pedagogical accompaniment of the orphaned children in the conditions of a foster family should be designed in accordance with the nature of the problem field of the foster family: the existing experience of the family upbringing 
of foster parents, the motivation for adopting an orphaned children into the family, the experience of living of an orphaned child in the family and the level of formation family values.

In accordance with the goals of family upbringing and family living arrangements for the orphaned children, the following criteria and indicators of the formation of family values in orphaned children and children left without parental care in the conditions of a foster family were identified: need-motivational (significant needs, manifestation of kinship feelings, value orientation to family life) cognitive (knowledge about the family and its role in human life; understanding of the relationship between family members); activity and practical (inclusion in the household life of the family, mastering housekeeping skills), emotional (mutual sympathy between family members, emotional state).

According to the results of the experimental work, a positive dynamics was revealed in the relations between the orphaned children and adoptive parents, which indicates the validity and effectiveness of the developed comprehensive program of psychological and pedagogical accompaniment for orphaned children and children left without parental care in the conditions of a foster family.

\section{SUMMARY}

This article deals with the psychological and pedagogical accompaniment of a foster family as a condition for the successful development and psychological health of orphaned children, which provides the best assimilation of basic family values and practical knowledge, skills and abilities. We consider it a holistic process, the main components of which are the creation of conditions for the development of family life competencies and personal achievements, as well as monitoring the formation of relevant knowledge and skills.

The comprehensive program of psychological and pedagogical accompaniment of the foster family includes the following blocks: target, content-related, organizational and monitoring. The goal of the comprehensive program of psychological and pedagogical accompaniment is the formation of family values in orphaned children and children left without parental care in the conditions of a foster family.

The result of the program is a positive change in views on the family, on the organization of family life, the formation of family values in 
orphaned children: respect for elders, participation in family affairs, friendly relations with all family members, etc., which in our opinion, testifies to the effectiveness of the measures taken.

\section{REFERENCES}

1. Аналітичний звіт «Життєвий шлях випускників інтернатних закладів, дитячих будинків сімейного типу та прийомних сімей» / О.М. Балакірєва, I. М. Чернін, О.М. Хмелевська та ін. К.: Український Інститут соціальних досліджень ім. О. Яременка, - 2010. - 106 с.

2. Бевз Г.М. Прийомна сім'я: соціально-психологічні виміри: Монографія / Г.М. Бевз. - К.: Видав. Дім «Слово», 2010. - 352 с.

3. Газман О.С. Педагогическая поддержка детей в образовании как ин-новационная проблема [Текст] / О.С. Газман // Новые ценности образования: десять концепций и эссе. 1995. № 3. С. 58-63.

4. Захист дітей, які потребують особливої уваги суспільства. Статистичний збірник. Київ - 2018. - Режим доступу: http:// www.ukrstat.gov.ua/druk/publicat/kat_u/2018/zb/07/zb_zdpus_2017.pdf

5. Комплексна допомога бездоглядним та безпритульним дітям: метод. посіб. / авт.: Безпалько О.В., Гурковська Л.П., Журавель Т.В. та ін. / за ред. Звєрєвої І.Д., Петрочко Ж.В. - К.: Видавничий дім «КАЛИТА», 2010. - 376 с.

6. Кузьмін В.В. Теоретичний аналіз проблеми інтеграції у суспільство дітей-сиріт та дітей, позбавлених батьківського піклування: соціально-психологічний аспект / В.В. Кузьмін // [Електронний ресурс]. - Режим доступу: http://journals.uran.ua/apppfo.

7. Курінна С. Проблема соціального супроводу дітей дошкільного віку в дитячому будинку / С. Курінна // Актуальні проблеми психолого-педагогічного та соціального супроводу дитини на ранніх етапах со-ціалізації. Гуманізація навчально-виховного процесу: Спецвипуск 4, Част. 1. - Слов'янськ. - 2010. - С. 198-203.

8. Кучерова О.Е. Становление Человека и основные каноны педагогической поддержки личности [Текст] / О.Е. Кучерова // Известия Академии педагогических и социальных наук. - 2008. Ч. II. - C. 174-178.

9. Малиночка Э.Г. О педагогическом сопровождении формирования и развития личности [Текст] / Э.Г. Малиночка. // Известия 
Академии педагогических и социальных наук. - 2008. - Ч. II. C. $162-168$.

10. Манохіна I.В. Соціально-педагогічна робота 3 дітьми-сиротами та дітьми, позбавленими батьківського піклування: навчальний посібник / I.B. Манохіна. - Дніпропетровськ: Дніпропетровський університет імені Альфреда Нобеля, 2012. - 276 с.

11. Машкаринець-Бутко А. Особливості роботи соціальних працівників у дитячих будинках сімейного типу / А. МашкаринецьБутко // Науковий вісник Ужгородського національного університету: серія «Педагогіка. Соціальна робота». - 2008. - № 14. - С. 98-101.

12. Психологічний супровід інклюзивної освіти : [метод. рек] / автор. кол. за заг. ред. А. Г. Обухівська. - Київ : УНМЦ практичної психології і соціальної роботи, 2017. - 92 с.

13. Холод В.Л., Холод А.В. Социально-педагогическая защита детей и молодежи в процессе психолого-педагогического сопровождения в условиях единого воспитательного пространства сельского района [Текст] / В.Л. Холод, А.В. Холод // Известия Академии педагогических и социальных наук. - 2008. - Ч. II. С. 196-202.

14. Шишко О.Я. Прийомна сім'я як спосіб вирішення проблеми соціального сирітства / О. Я. Шишко // Психологія особистості. 2010. - № 1. - C. 210-218.

\section{Information about the author:} Dobrovolska N. A. $\operatorname{Dr}(\mathrm{PhD})$,

Head of the Department of Physical Education, Sports and Human Health of the V. I. Vernadsky Taurida National University 33, Ivana Kydri str., Kyiv, 01042, Ukraine 